\title{
Future Directions in Stratigraphy
}

A special planning meeting on Future Directions in Stratigraphy by the International Commission on Stratigraphy (ICS) in Urbino, Italy on 14-16 June 2002 established an ambitious plan for the next decade. The following are some highlights of this firstever assembly of all ICS voting members. The complete report is available at the ICS website: www.stratigraphy.org.

\section{ICS mission}

The International Commission on Stratigraphy is the primary body for facilitation of international communication and scientific cooperation in stratigraphy, defined in the broad sense of multidisciplinary activities directed towards better understanding of Earth history. The ICS needs to excite the next generation with new tools, high-resolution event correlation on a global scale, and other projects with relevance to public concerns and imagination.

To accomplish this mission, the Commission establishes several strategic goals, including:

\section{Completion of international standards}

a. A total commitment by the stratigraphic subcommissions to assign boundary stratotypes for the entire Phanerozoic by the year 2008 .

Attached to this report is a comprehensive table of ratified and in-progress boundary stratotypes for the geological time scale (Table 1). Color charts (PDFs) of the associated geological time scale can be downloaded from the Commission website (www.stratigraphy.org), and the on-line versions of this table and chart are being continually updated as each international geological stage is formally defined.

b. Revitalization of a Subcommission on Quaternary Stratigraphy scientifically linked with INQUA to propose major subdivisions of the Pleistocene and the base of the Holocene.

2. Enhanced ICS visibility and publications

a. More effective and broader publication and distribution of the scientific accomplishments of ICS, particularly with respect to new stratigraphic standards, time scale, color codes, stratigraphic guidelines and nomenclature.

b. A business-like approach to creation and marketing of important stratigraphic products such as geologic time scale posters, boundary stratotype standard brochures, international stratigraphic guide, stratigraphic teaching modules on $\mathrm{CD}$, and major stratigraphic datasets.

c. A stratigraphic scientific journal sponsored by ICS, which would receive a por-

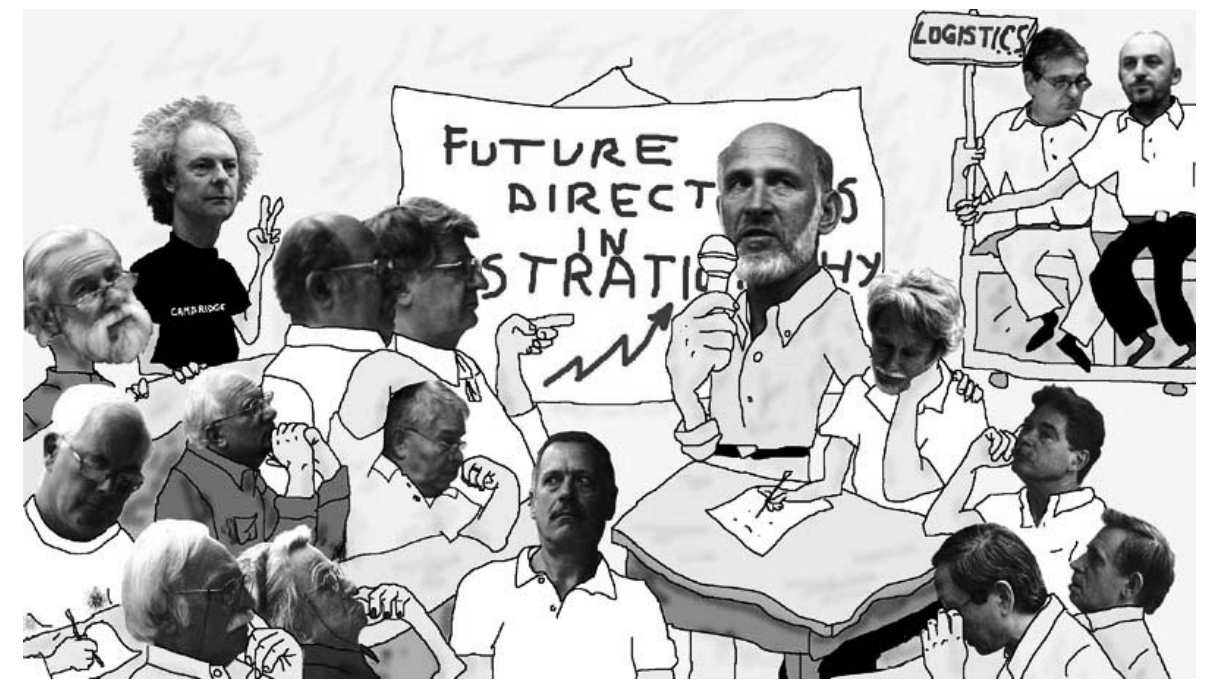

Officers of ICS and invited participants in active debate during the special meeting in Urbino, Italy on 'Future Directions in Stratigraphy'

tion of the income. One possibility is an upgraded and expanded Newsletter in Stratigraphy.

d. An electronic stratigraphic 'journal' with full-fledged articles and databases to link and complement the printed journal of ICS.

e. A theme-oriented popular stratigraphic journal directed toward understanding new stratigraphic concepts and events. This journal would have beautiful front-page covers, full color images, and general-geology level of review articles on exciting topics.

f. International stratigraphic prizes (Hedberg and Steno) to be awarded every 4th year coincident with the IGC.

g. Potential creation of the 'International Association of Stratigraphic Geologists' (IASG) maintaining close ties with IUGS and preserving a major part of the present Subcommission structure with unique expertise for major Periods of the stratigraphic column.

3. Coordination of comprehensive stratigraphic databases (e.g., CHRONOS system)

The principle goals of the CHRONOS initiative are:

- Assembly, integration and distribution of data relevant to geologic time.

- Maintenance of a consensus geological timescale.

- Public outreach-Communicate to the public the importance of understanding rates in natural processes using the geological timescale.

- Research outreach-Provide a fundamental research tool for the broader geoscience community and a temporal framework for understanding the 4th dimension (rates and processes).

The suite of CHRONOS databases includes all chronostratigraphic data:

- Life-paleontological assemblages, evolution, biodiversity, ...

- Climate-orbital forcing, oxygen isotopes, ecosystem changes, ...

- Surface processes-biogeochemical cycle monitors, strontium isotopes, ...

- Care-Mantle dynamics-magnetic reversals and intensity trends, plate motions ...

- Catastrophic episodes-impact-related anomalies, oceanic anoxia episodes, ...

- Time-absolute ages and relative ages, stage boundaries, ...

Further information on the CHRONOS concept is available at <www.eas.purdue.edu/ chronos/>.

\section{Acknowledgements}

The ICS thanks Stan Finney (ICS vice-chair) for organizing the meeting, and is very grateful to Prof. Rodolpho Coccioni and Dr. Simone Galeotti of the University of Urbino for hosting this conference and the associated scientific program. Financial support for Urbino conference logistics was provided by the IUGS, and travel support for several participants was from a special grant from ICSU.

Felix Gradstein

(ICS chair,felix.gradstein@nhm.uio.no)

\section{James Ogg}

(ICS secretary general,jogg@purdue.edu) 
Table 1 Overview of Global Boundary Stratotype Sections and Points (GSSPs) (compiled by Jim Ogg)

\begin{tabular}{|c|c|c|c|c|}
\hline $\begin{array}{l}\text { EON, Era, System, } \\
\text { Series, Stage }\end{array}$ & Principal correlative events & GSSP and Iocation & Status & Publication \\
\hline \multicolumn{5}{|l|}{ PHANEROZOIC } \\
\hline \multicolumn{5}{|l|}{ Cenozoic Era } \\
\hline Neogene System & $\begin{array}{l}\text { "Quaternary" is traditionally considered to be the } \\
\text { interval of oscillating climatic extremes (glacial and } \\
\text { interglacial episodes) encompassing Holocene and } \\
\text { Pleistocene. }\end{array}$ & & & \\
\hline \multicolumn{5}{|l|}{ Holocene Series } \\
\hline base Holocene & $\begin{array}{l}\text { Exactly } 10,000 \text { Carbon-14 years }(=11.5 \text { ka calendar } \\
\text { years BP) at the end of the Younger Dryas cold spell }\end{array}$ & & $\begin{array}{l}\text { Informal working } \\
\text { definition }\end{array}$ & \\
\hline \multicolumn{5}{|l|}{ Pleistocene Series } \\
\hline base Upper Pleistocene subseries & $\begin{array}{l}\text { Base of the Eemian interglacial stage (= base of } \\
\text { marine isotope stage } 5 \mathrm{e} \text {, before final glacial episode } \\
\text { of Pleistocene) at } \sim 126 \mathrm{ka} \text {. }\end{array}$ & $\begin{array}{l}\text { Potentially, within sediment core under } \\
\text { the Netherlands (Eemian type area) }\end{array}$ & $\begin{array}{l}\text { Informal working } \\
\text { definition }\end{array}$ & \\
\hline base Middle Pleistocene subseries & Brunhes-Matuyama magnetic reversal, $\sim 780,000$ BP & & $\begin{array}{l}\text { Informal working } \\
\text { definition }\end{array}$ & \\
\hline base Pleistocene Series & $\begin{array}{l}\text { Just above top of magnetic polarity chronozone C2n } \\
\text { (Olduvai) and the extinction level of calcareous } \\
\text { nannofossil Discoaster brouweri (base Zone CN13) } \\
\text { Astrochronology age of } 1.806 \mathrm{Ma} \text {. Above are lowest } \\
\text { occurrence of calcareous nannofossil medium } \\
\text { Gephyrocapsa spp. and extinction level of planktonic } \\
\text { foraminifer Globigerinoides extremus. }\end{array}$ & $\begin{array}{l}\text { Base of sapropel layer 'e', Vrica, } \\
\text { Calabria, Italy }\end{array}$ & Ratified 1985 & $\begin{array}{l}\text { Episodes } 8(2) \\
\text { p.116-120, } 1985\end{array}$ \\
\hline \multicolumn{5}{|l|}{ Pliocene Series } \\
\hline base Gelasian Stage & $\begin{array}{l}\text { Isotopic stage } 103 \text { ( } 2.588 \mathrm{Ma} \text { ), base of magnetic } \\
\text { polarity chronozone } \mathrm{C} 2 \mathrm{r} \text { (Matuyama). Above are } \\
\text { extinction levels of calcareous nannofossil Discoaster } \\
\text { pentaradiatus and D. surculus (base Zone CN12c). }\end{array}$ & $\begin{array}{l}\text { Top of sapropelic Nicola Bed, Monte } \\
\text { San Nicola, Gela, Sicily, Italy }\end{array}$ & Ratified 1996 & $\begin{array}{l}\text { Episodes } 21(2) \\
\text { p.82-87, } 1998\end{array}$ \\
\hline base Piacenzian Stage & $\begin{array}{l}\text { Base of magnetic polarity chronozone C2An (Gauss); } \\
\text { astrochronology age of } 3.600 \mathrm{Ma} \text {; extinction levels of } \\
\text { planktonic foraminifers Globorotalia margaritae (base } \\
\text { Zone PL3) and Pulleniatina primalis. }\end{array}$ & $\begin{array}{l}\text { Carbonate cycle } 77 \text {, Punta Piccola, } \\
\text { Sicily, Italy }\end{array}$ & Ratified 1997 & $\begin{array}{l}\text { Episodes } 21(2) \\
\text { p.88-93, } 1998\end{array}$ \\
\hline $\begin{array}{l}\text { base Zanclean Stage, base } \\
\text { Pliocene Series }\end{array}$ & $\begin{array}{l}\text { Astrochronology age of } 5.333 \mathrm{Ma} \text {. Top of magnetic } \\
\text { polarity chronozone C3r, } 100 \mathrm{kyr} \text { before Thvera } \\
\text { normal-polarity subchronozone (C } 3 \mathrm{n} .4 \mathrm{n}) \text {. Calcareous } \\
\text { nannofossils -- near extinction level of } \\
\text { Triquetrorhabdulus rugosus (base Zone CN10b) and } \\
\text { the lowest occurrence of Ceratolithus acutus. }\end{array}$ & $\begin{array}{l}\text { Base of Trubi Fm, Eraclea Minoa, } \\
\text { Sicily, Italy }\end{array}$ & Ratified 2000 & $\begin{array}{l}\text { Episodes } 23(3) \\
\text { p.179-187, } 2000\end{array}$ \\
\hline \multicolumn{5}{|l|}{ Miocene Series } \\
\hline base Messinian Stage & $\begin{array}{l}\text { Astrochronology age of } 7.251 \mathrm{Ma} \text {; middle of magnetic } \\
\text { polarity chronozone } \mathrm{C} 3 \mathrm{Br} \text {.1r; lowest regular } \\
\text { occurrence of the Globorotalia conomiozea planktonic } \\
\text { foraminifer group. }\end{array}$ & $\begin{array}{l}\text { Carbonate cycle OA-15, Oued Akrech, } \\
\text { Rabat, Morocco }\end{array}$ & Ratified 2000 & $\begin{array}{l}\text { Episodes } 23(3) \\
\text { p.172-178, } 2000\end{array}$ \\
\hline base Tortonian Stage & Upper part of magnetic polarity chronozone $\mathrm{C} 5 \mathrm{r}$ & & $\begin{array}{l}\text { Guide event is } \\
\text { undecided }\end{array}$ & \\
\hline base Serravillian Stage & $\begin{array}{l}\text { Near lowest occurrence of nannofossil Sphenolithus } \\
\text { heteromorphus, and within magnetic polarity } \\
\text { chronozone C5ABr. }\end{array}$ & & $\begin{array}{l}\text { GSSP anticipated in } \\
2003\end{array}$ & \\
\hline base Langhian Stage & $\begin{array}{l}\text { Near lowest occurrence of planktonic foraminifer } \\
\text { Praeorbulina sicana, near middle of magnetic polarity } \\
\text { chronozone } C 5 \mathrm{Cn} .2 \mathrm{n}\end{array}$ & & $\begin{array}{l}\text { Guide event is } \\
\text { undecided }\end{array}$ & \\
\hline base Burdigalian Stage & $\begin{array}{l}\text { Near lowest occurrence of planktonic foraminifer } \\
\text { Globigerinoides altiaperturus or top of magnetic } \\
\text { polarity chronozone C6An }\end{array}$ & & $\begin{array}{l}\text { Guide event is } \\
\text { undecided }\end{array}$ & \\
\hline $\begin{array}{l}\text { base Aquitanian Stage, base } \\
\text { Miocene Series, base Neogene } \\
\text { System }\end{array}$ & $\begin{array}{l}\text { Base of magnetic polarity chronozone } \mathrm{C} 6 \mathrm{Cn} .2 \mathrm{n} \text {; } \\
\text { lowest occurrence of planktonic foraminifer } \\
\text { Paragloborotalia kugleri; near extinction of calcareous } \\
\text { nannofossil Reticulofenestra bisecta (base Zone NN1). }\end{array}$ & $\begin{array}{l}35 \mathrm{~m} \text { from top of Lemme-Carrosio } \\
\text { section, Carrosio village, north of } \\
\text { Genoa, Italy }\end{array}$ & Ratified 1996 & $\begin{array}{l}\text { Episodes } 20(1) \\
\text { p.23-28, } 1997\end{array}$ \\
\hline \multicolumn{5}{|l|}{ Paleogene System } \\
\hline \multicolumn{5}{|l|}{ Oligocene Series } \\
\hline base Chattian Stage & $\begin{array}{l}\begin{array}{l}\text { Planktonic foraminifer, extinction of Chiloguembelina } \\
\text { (base Zone P } 21 \text { b) }\end{array} \\
\end{array}$ & $\begin{array}{l}\text { Probably in Umbria-Marche region of } \\
\text { Italy }\end{array}$ & $\begin{array}{l}\text { GSSP anticipated in } \\
2003\end{array}$ & \\
\hline $\begin{array}{l}\text { base Rupelian Stage, base } \\
\text { Oligocene Series }\end{array}$ & Planktonic foraminifer, extinction of Hantkenina & $\begin{array}{l}\text { Base of marl bed at } 19 \mathrm{~m} \text { above base } \\
\text { of Massignano quarry, Ancona, Italy }\end{array}$ & Ratified 1992 & \begin{tabular}{|l|} 
Episodes $16(3)$, \\
p.379-382, 1993 \\
\end{tabular} \\
\hline \multicolumn{5}{|l|}{ Eocene Series } \\
\hline base Priabonian Stage & $\begin{array}{l}\text { Near lowest occurrence of calcareous nannofossil } \\
\text { Chiasmolithus oamaruensis (base Zone NP18) } \\
\end{array}$ & $\begin{array}{l}\begin{array}{l}\text { Probably in Umbria-Marche region of } \\
\text { Italy }\end{array} \\
\end{array}$ & & \\
\hline base Bartonian Stage & $\begin{array}{l}\text { Near extinction of calcareous nannofossil } \\
\text { Reticulofenestra reticulata }\end{array}$ & & & \\
\hline base Lutetian Stage & $\begin{array}{l}\text { Planktonic foraminifer, lowest occurrence of } \\
\text { Hantkenina }\end{array}$ & $\begin{array}{l}\text { Leading candidate is Fortuna section, } \\
\text { Murcia province, Betic Cordilleras, Spain }\end{array}$ & $\begin{array}{l}\text { GSSP anticipated in } \\
2003\end{array}$ & \\
\hline $\begin{array}{l}\text { base Ypresian Stage, base } \\
\text { Eocene Series }\end{array}$ & Base of negative carbon-isotope excursion & Dababiya Section near Luxor, Egypt & $\begin{array}{l}\text { GSSP anticipated in } \\
2002\end{array}$ & \\
\hline
\end{tabular}




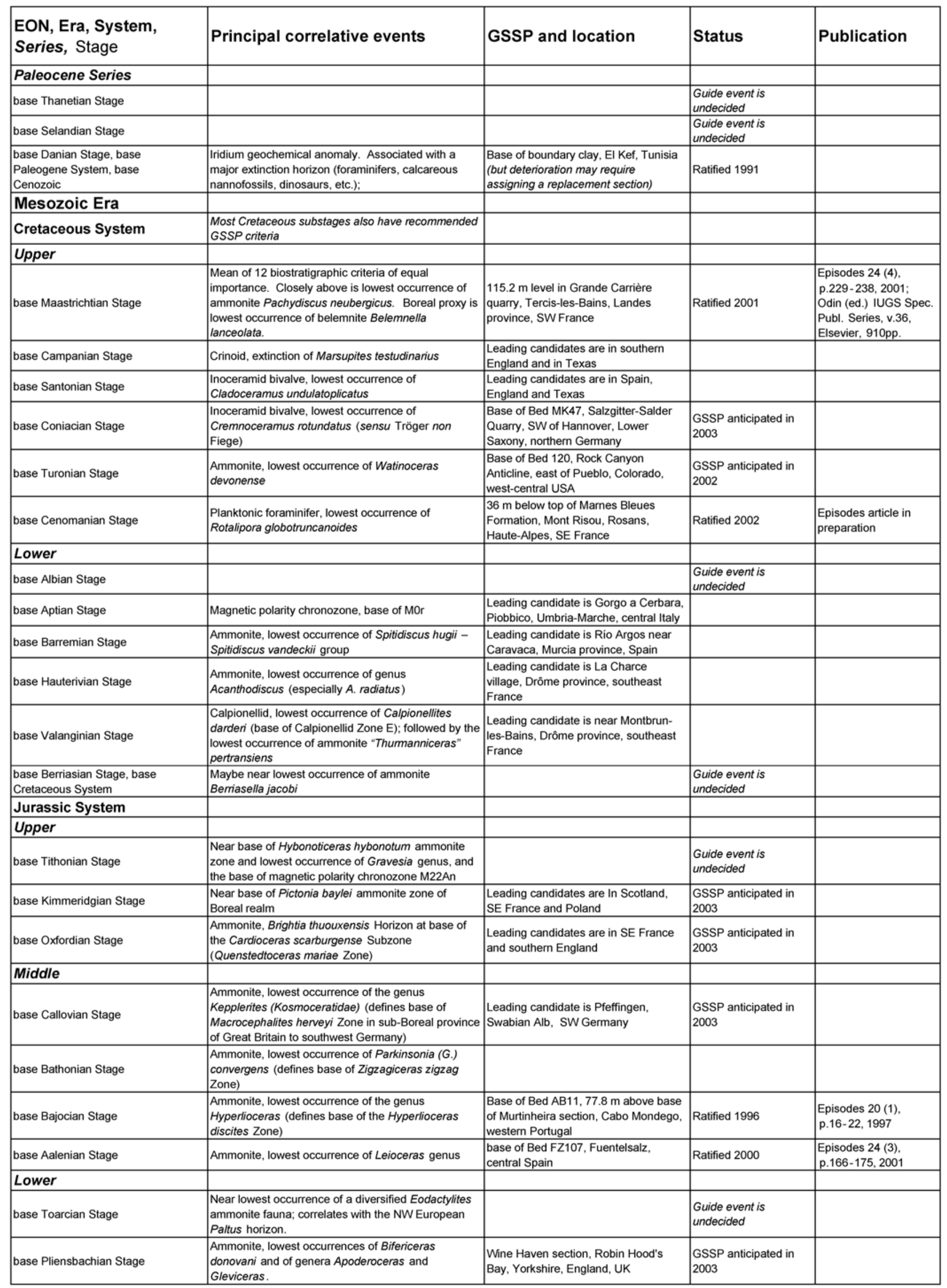




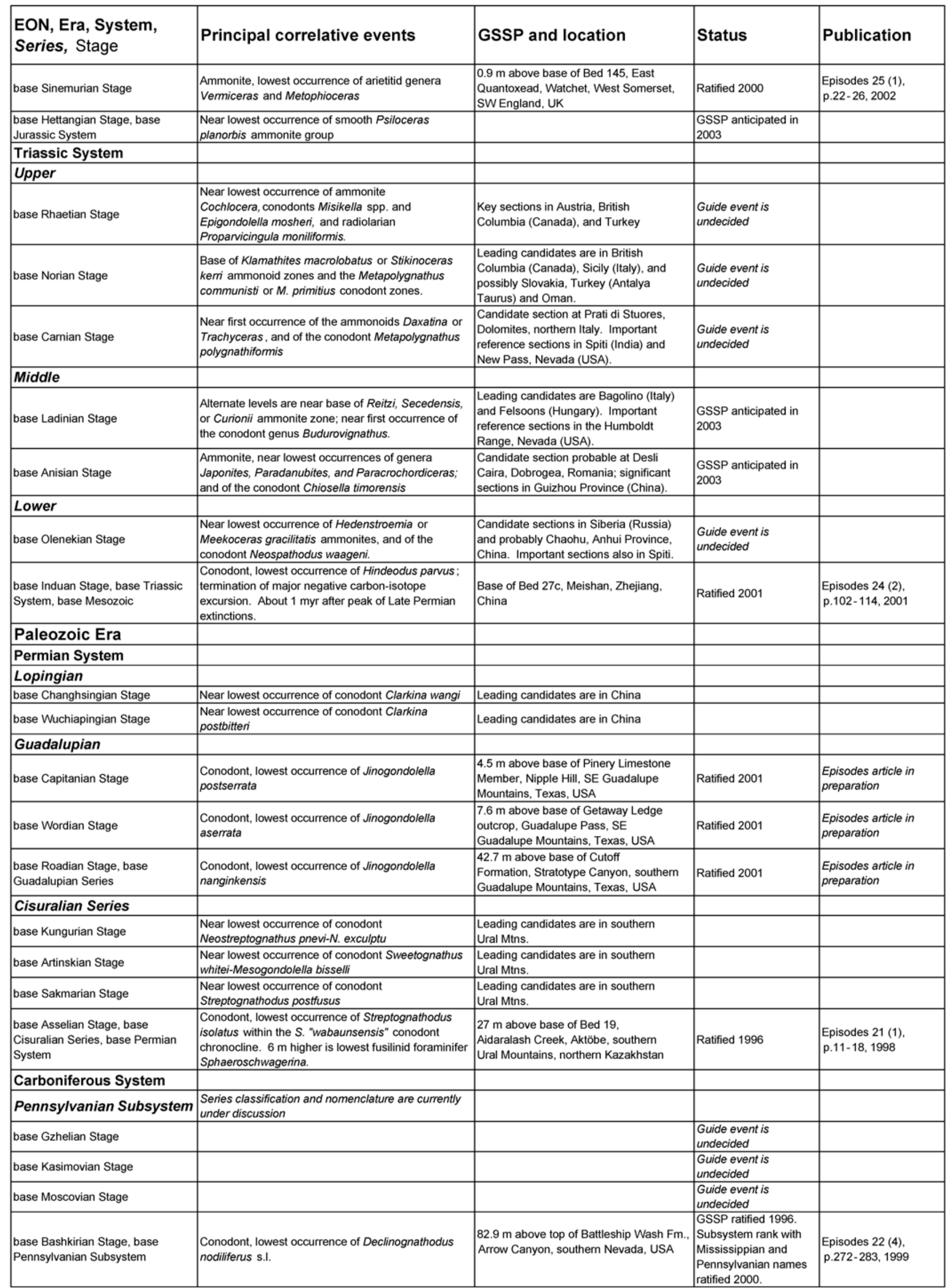




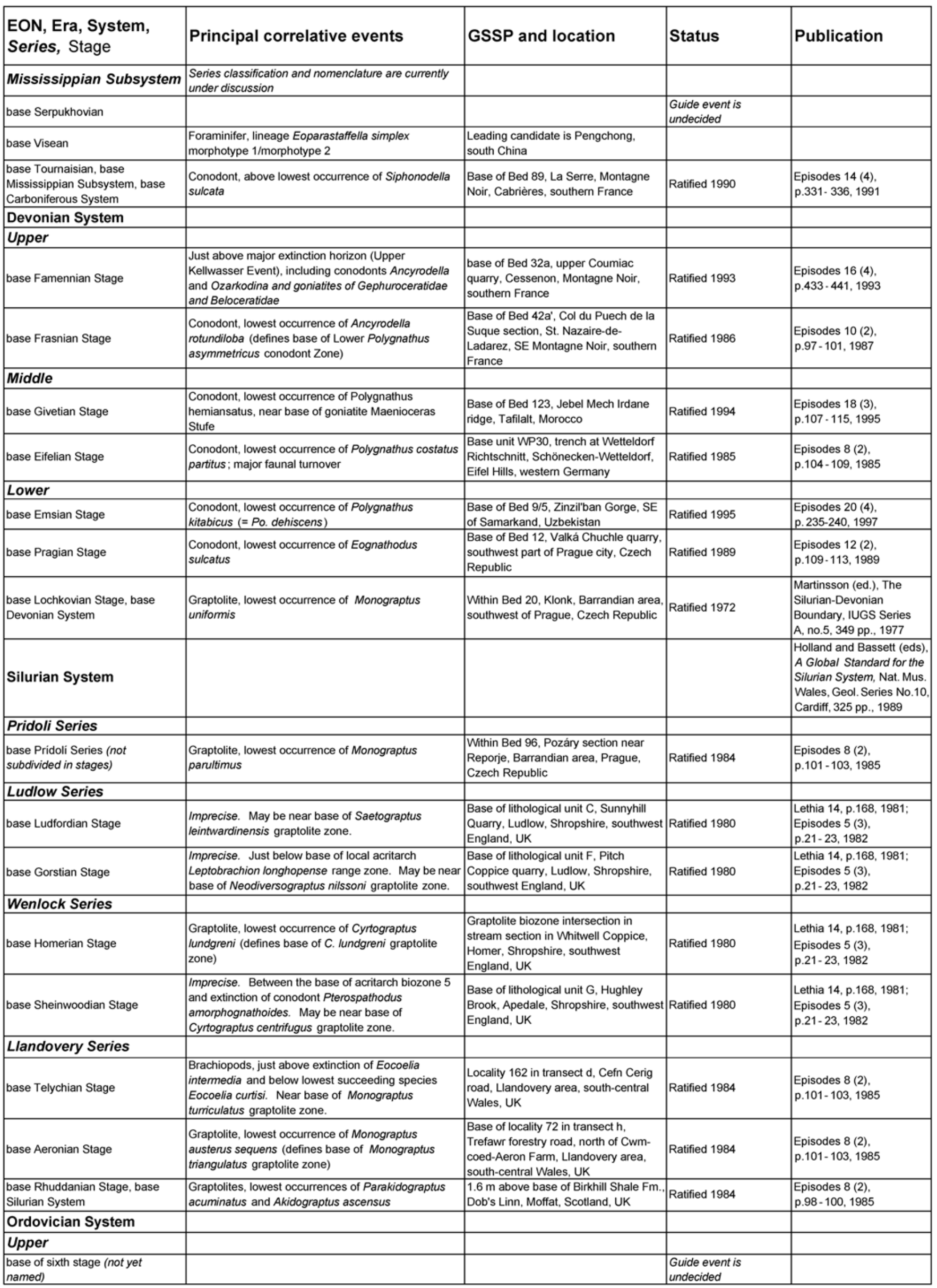




\begin{tabular}{|c|c|c|c|c|}
\hline $\begin{array}{l}\text { EON, Era, System, } \\
\text { Series, Stage }\end{array}$ & Principal correlative events & GSSP and location & Status & Publication \\
\hline base of fifth stage (not yet named) & Graptolite, lowest occurrence of Nemagraptus gracilis & $\begin{array}{l}1.4 \mathrm{~m} \text { below phosphorite in E14a } \\
\text { outcrop, Fágelsáng, Scane, southern } \\
\text { Sweden }\end{array}$ & Ratified 2002 & $\begin{array}{l}\text { Episodes } 23(2), \\
\text { p.102-109, 2000 } \\
\text { (proposal; formal } \\
\text { GSSP publication in } \\
\text { preparation). }\end{array}$ \\
\hline \multicolumn{5}{|l|}{ Middle } \\
\hline base Darriwillian Stage & $\begin{array}{l}\text { Graptolite, lowest occurrence of Undulograptus } \\
\text { austrodentatus }\end{array}$ & $\begin{array}{l}\text { Base of Bed AEP184, } 22 \mathrm{~m} \text { below top } \\
\text { of Ningkuo Fm., Huangnitang, } \\
\text { Changshan, Zhejiang province, } \\
\text { southeast China }\end{array}$ & Ratified 1997 & $\begin{array}{l}\text { Episodes } 20(3) \\
\text { p.158-166, } 1997\end{array}$ \\
\hline base of third stage (not yet named) & Conodont, lowest occurrence of Tripodus laevis & & & \\
\hline \multicolumn{5}{|l|}{ Lower } \\
\hline $\begin{array}{l}\text { base of second stage (not yet } \\
\text { named) }\end{array}$ & $\begin{array}{l}\text { Graptolite, lowest occurrence of Tetragraptus } \\
\text { approximatus }\end{array}$ & $\begin{array}{l}\text { Just above E bed, Diabasbrottet } \\
\text { quarry, Västergötland, southern } \\
\text { Sweden }\end{array}$ & Ratified 2002 & $\begin{array}{l}\text { Episodes article in } \\
\text { preparation }\end{array}$ \\
\hline $\begin{array}{l}\text { base of Tremadocian Stage, base } \\
\text { Ordovician System }\end{array}$ & $\begin{array}{l}\text { Conodont, lowest occurrence of lapetognathus } \\
\text { fluctivagus; just above base of Cordylodus lindstromi } \\
\text { conodont Zone. Just below lowest occurrence of } \\
\text { planktonic graptolites. Currently dated around } 489 \\
\text { Ma. }\end{array}$ & $\begin{array}{l}\text { Within Bed } 23 \text { at the } 101.8 \mathrm{~m} \text { level, } \\
\text { Green Point, western Newfoundland, } \\
\text { Canada }\end{array}$ & Ratified 2000 & $\begin{array}{l}\text { Episodes } 24(1) \\
\text { p.19-28, }\end{array}$ \\
\hline Cambrian System & $\begin{array}{l}\text { Potential GSSP correlation levels include Cordylodus } \\
\text { proavus, Glyptagnostus reticulatus, Ptychagnostus } \\
\text { punctuosus, Acidusus atavus, and Oryctocephalus } \\
\text { indicus. }\end{array}$ & & $\begin{array}{l}\text { Overview of potential } \\
\text { subdivisions is in } \\
\text { Episodes } 23(3) \\
\text { p.188-195, 2000. }\end{array}$ & \\
\hline \multicolumn{5}{|l|}{$\begin{array}{l}\text { Upper ("Furongian") } \\
\text { Series }\end{array}$} \\
\hline upper stage(s) in Furongian & $\begin{array}{l}\text { Potential GSSP levels in upper Cambrian are based } \\
\text { on trilobites and condonts }\end{array}$ & & & \\
\hline $\begin{array}{l}\text { base Paibian Stage, base } \\
\text { Furongian Series }\end{array}$ & $\begin{array}{l}\text { Trilobite, lowest occurrence of agnostoid } \\
\text { Glyptagnostus reticulatus. Coincides with base of } \\
\text { large positive carbon-isotope excursion. }\end{array}$ & $\begin{array}{l}369.06 \mathrm{~m} \text { above base of Huaqiao } \mathrm{Fm}, \\
\text { Paibi section, NW Hunan province, } \\
\text { south China }\end{array}$ & $\begin{array}{l}\text { Currently undergoing } \\
\text { ICS vote (May 2002) }\end{array}$ & \\
\hline Middle & $\begin{array}{l}\text { Potential GSSP levels in Middle Cambrian are based } \\
\text { mainly on trilobites }\end{array}$ & & & \\
\hline Lower & $\begin{array}{l}\text { Potential GSSP levels in Lower Cambrian are based } \\
\text { on archaeocyatha, small shelly fossils, and to a lesser } \\
\text { extent, trilobites }\end{array}$ & & & \\
\hline $\begin{array}{l}\text { base Cambrian System, base } \\
\text { Paleozoic, base PHANEROZOIC }\end{array}$ & $\begin{array}{l}\text { Trace fossil, lowest occurrence of Treptichnus } \\
\text { (Phycodes) pedum. Near base of negative carbon- } \\
\text { isotope excursion. Currently dated at } 543.3 \mathrm{Ma} \text {. }\end{array}$ & $\begin{array}{l}2.4 \mathrm{~m} \text { above base of Member } 2 \text { of } \\
\text { Chapel Island Fm., Fortune Head, } \\
\text { Burin Peninsula, southeast } \\
\text { Newfoundland, Canada }\end{array}$ & Ratified 1992 & $\begin{array}{l}\text { Episodes } 17 \text { (1\&2), } \\
\text { p.95-100, } 1994 .\end{array}$ \\
\hline PROTEROZOIC & $\begin{array}{l}\text { Pre-Cambrian eras and systems are defined by } \\
\text { absolute ages, rather than stratigraphic points. }\end{array}$ & & & \\
\hline \multicolumn{5}{|l|}{ Neoproterozoic Era } \\
\hline $\begin{array}{l}\text { Neoproterozoic III } \\
\text { ("Terminal Proterozoic } \\
\text { System" -- name to be } \\
\text { decided) }\end{array}$ & $\begin{array}{l}\text { Base }=650 \mathrm{Ma} \text { (previous definition). Potential GSSP } \\
\text { correlative event is termination of the } \\
\text { Varanger/Maringan glaciation. }\end{array}$ & & $\begin{array}{l}\text { Age-definition ratified in } \\
1990, \text { but will be } \\
\text { replaced by a } \\
\text { stratigraphic GSSP }\end{array}$ & $\begin{array}{l}\text { Episodes } 14 \text { (2), } \\
\text { p.139-140, } 1991\end{array}$ \\
\hline Cryogenian System & Base $=850 \mathrm{Ma}$ & & & \\
\hline Tonian System & Base $=1000 \mathrm{Ma}$ & & Ratified 1990 & \begin{tabular}{|l|} 
Episodes 14 (2), \\
p.139-140, 1991
\end{tabular} \\
\hline \multicolumn{5}{|l|}{ Mesoproterozoic Era } \\
\hline Stenian System & Base $=1200 \mathrm{Ma}$ & & Ratified 1990 & \begin{tabular}{|l|} 
Episodes $14(2)$ \\
p.139-140, 1991
\end{tabular} \\
\hline Ectasian System & Base $=1400 \mathrm{Ma}$ & & Ratified 1990 & $\begin{array}{l}\text { Episodes } 14(2), \\
\text { p.139-140, } 1991\end{array}$ \\
\hline Calymmian System & Base $=1600 \mathrm{Ma}$ & & Ratified 1990 & $\begin{array}{l}\text { Episodes 14 (2), } \\
\text { p.139-140, } 1991\end{array}$ \\
\hline \multicolumn{5}{|l|}{ Paleoproterozoic Era } \\
\hline Statherian System & Base $=1800 \mathrm{Ma}$ & & Ratified 1990 & \begin{tabular}{|l|} 
Episodes 14 (2), \\
p.139-140, 1991
\end{tabular} \\
\hline Orosirian System & Base $=2050 \mathrm{Ma}$ & & Ratified 1990 & $\begin{array}{l}\text { Episodes 14 (2), } \\
\text { p.139-140, } 1991\end{array}$ \\
\hline Rhyacian System & Base $=2300 \mathrm{Ma}$ & & Ratified 1990 & $\begin{array}{l}\text { Episodes } 14(2), \\
\text { p.139-140, } 1991\end{array}$ \\
\hline Siderian System & Base $=2500 \mathrm{Ma}$ & & Ratified 1990 & $\begin{array}{l}\text { Episodes 14 (2), } \\
\text { p.139-140, } 1991\end{array}$ \\
\hline \multicolumn{5}{|l|}{ ARCHEAN } \\
\hline Neoarchean Era & Base $=2800 \mathrm{Ma}$ & & Ratified 1990 & \begin{tabular}{|l|} 
Episodes $14(2)$, \\
p.139-140, 1991
\end{tabular} \\
\hline Mesoarchean Era & Base $=3200 \mathrm{Ma}$ & & Ratified 1990 & $\begin{array}{l}\text { Episodes 14 (2), } \\
\text { p.139-140, } 1991\end{array}$ \\
\hline Paleoarchean Era & Base $=3600 \mathrm{Ma}$ & & Ratified 1990 & $\begin{array}{l}\text { Episodes 14 (2), } \\
\text { p.139-140, } 1991\end{array}$ \\
\hline Eoarchean Era & Base $=?$ & & & \\
\hline
\end{tabular}




\section{The Geological Society of Australia is fifty years old}

\section{The beginning}

Fifty years ago this year at meetings held on 21 and 25 August 1952, the present Geological Society of Australia was created. The meetings were held during the ANZAAS (Australian and New Zealand Association for the Advancement of Science) conference at the University of Sydney.

A draft constitution was endorsed that had been prepared by a Provisional Committee with nationwide representation including: Chairman: E.S. Hills (also representing Victoria),

Secretary: C. Teichert, N.H. Fisher (Australian Capital Territory), C.E. Marshall (New South Wales), W.H. Bryan (Queensland), M.F. Glaessner (South Australia), M.R. Banks (Tasmania), O.P. Singleton (Western Australia).

The Provisional Committee had been formed in May 1951 to discuss a proposal from West Australian geologist R.W. Fairbridge for the establishment of an 'Australian Geological Institute'.

Formal formation of regional Divisions of the Society occurred during the same period with principal office bearers as follows :

Tasmania (Hobart), 18 June 1952

Chair: C. Loftus Hill

Secretary: M.R. Banks

ACT (Canberra) 27, November 1952

Chair: A.A. Opik

Secretary: I. Crespin

New South Wales (Sydney), 4 December 1952

Chair: C.E. Marshall

Secretary: H.O. Fletcher

Western Australia (Perth), 15 December 1952 Chair: R.T. Prider

Secretary: O.P. Singleton

Queensland (Brisbane), 17 December 1952

Chair: W.H. Bryan

Secretary: W.D. Mott

South Australia (Adelaide), 12 March 1953

Chair: M.F. Glaessner

Secretary: N.H. Ludbrook

Victoria (Melbourne), 23 April 1953

Chair: D.E. Thomas;

Secretary: E.S. Hills

(A Northern Territory Division was formally formed in Darwin much later in July 1998)

Subsequently in June 1953, the first national executive of the Society was constituted as follows:

President: E.S. Hills

Secretary: C. Teichert

Treasurer: O.A. Jones

Editor: M.F. Glaessner

Newsletter Editor: B.F. Glenister
By the end of 1953, the Society had 424 members with the largest number (96) in Victoria. On the eve of the mining boom in 1968, membership had reached 1472 with the largest Division being NSW with 340 members. By 1984, overall membership numbers reached an all-time peak of 3449. In 2002, membership totalled 2830 with most members based in Western Australia followed by New South Wales and Queensland.

\section{Developing national organisation}

A major driving force behind the establishment of the Society was E.S. Hills (University of Melbourne) who became the Society's Foundation President. His then colleague in Melbourne, C. Teichert, was also the first Secretary.

From 1960, the Constitution provided for designation of an Executive Division amongst Divisions which provided the President, Secretary and Treasurer, and administered the Society on a day-to-day basis. Early executives were elected at plenary meetings that were held in conjunction with ANZAAS conferences. The Society maintained this ongoing liaison until August 1973 when Council decided that transfer of Executive responsibility to another Division would be linked subsequently to the Australian Geological Conventions.

In the early years of the Society, the affairs of the Society were conducted entirely on a voluntary basis. The Treasurer depended on Divisional Treasurers to collect fees for the Society. In 1960, through the efforts of President N.H. Fisher and Treasurer C.V. Phipps, the Society set up a permanent office in Sydney initially with ANZAAS in Science House at 157 Gloucester Street, Sydney. The Society continues to maintain a permanent office, now at Suite 706, 301 George St., Sydney under a Business Manager (currently Mrs Misha Frankel).

In 1958, Honorary Membership was first introduced into the Rules of the Society, and W.R. Browne, L.A. Cotton, D. Mawson, F.L. Stillwell, L.K. Ward and W.G. Woolnough were elected at the same general meeting. The 1958 Constitution also provided for Honorary Correspondents to represent the Society outside Australia. L.G. Weeks, an American petroleum geologist, well known for his critical studies which led to the discovery of petroleum in offshore Bass Strait, was elected as the first Honorary Correspondent in 1968. Much later, in 1993, the category of "Fellow" was created for practising geologists

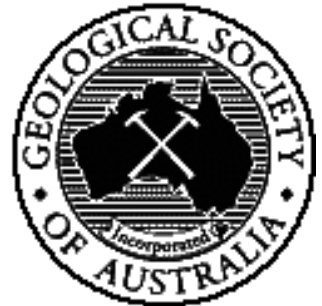

with at least 10 years experience, who have served the Society in an executive function.

The 1970s and 1980s were a period of growing maturity. In 1981, the Society was instrumental in sponsoring and co-ordinating the establishment of the Australian Geoscience Council in 1981. The AGC is designed to present the diverse views of the geoscience professions in Australia on matters of national and international importance.

The 1990s saw a surge of interest in geoscience promotion. In 1992, G.K. Krummei was appointed the Society's first Promotions Officer. A salaried Promotions and Education Manager position was approved in 1998 with this post now shifting geographically with moves of the Executive.

\section{Specialist groups}

The formation of Specialist Groups was not anticipated by the founders of the Society and their development was a product of the 1960s.

In 1964, concern was expressed that specialist earth science organisations were developing and should be encouraged to remain within the Society. A new Rule providing for the formation of specialist groups was prepared and accepted at a General Meeting of the Society in Melbourne in January 1967. Before their formal recognition, informal groups organised a specialists meeting in Adelaide in August 1966. The original dates of approval of each Specialist Group and their inaugural Chair are as follows :

Sedimentology, May 1968

Chair: J.J. Veevers

(now Australasian Sedimentologists Group)

Geochemistry \& Mineralogy, May 1968

Chair: J.F. Lovering

(now Geochemistry Mineralogy \& Petrology)

Palaeontology \& Biostratigraphy, June 1968

Chair: M.F. Glaessner

(now Australasian Association of

Palaeontologists)

Genesis of Ore Deposits, October 1968

Chair: H.F. King

(now Economic Geology)

Tectonics \& Structural Geology, February 1972 Chair: E. Scheibner

Coal Geology, February 1977 Chair: J.W. Beeston

Engineering Geology, August 1978 Chair: N.M. Gray (now Environmental, Engineering \& Hydrogeology)

Earth Sciences History, August 1984 Chair: B.J. Cooper 
Solid Earth Geophysics, August 1984

Chair: D. Denham

Computing, September 1994

Chair: R.J. Ryburn

Applied Geochemistry, September 1994

Chair: P.S. Ward

Education, February 1996

Chair: L.H. Hamilton

Volcanology, July 1998

Chair: E.J. Arundell

Since their creation, Specialist Groups have provided valuable additional strength and dimension to the Society, especially in the areas of conferences and publications.

\section{The journal and special publications}

A primary purpose of the Society at its foundation was the establishment of a national publication for geological research. Soon after the establishment of the Society, the first volume of the Journal of the Geological Society of Australia appeared in June 1954. The titles and authors of published papers in Volume 1 were:

A.B. Edwards \& G. Baker-Scapolitization in the Cloncurry District of northwestern Queensland.

R.O. Brunnschweiler-Mesozoic stratigraphy of the Canning Desert and Fitzroy Valley, Western Australia.

E. den Tex-Stereographic distinction of linear and planar structures from apparent lineations in random exposure planes.

S.W. Carey-The Rheid concept in geotectonics.

E.S. Hills \& D.E. Thomas-Turbidity currents and the graptolitic facies in Victoria.

For the first three years, the Journal was issued as one volume annually. Then in 1957, publication of "collective accounts" of the geology of Australia were initiated. The Stratigraphy of Western Australia was issued as Part 2 of Volume 4. Later in the same year, the Geology of South Australia was published. This was followed by further volumes through the 1960s, culminating with the Geology of New South Wales in 1969. Geologists quickly recognised that these volumes provided the only up-to-date accounts of the geology of Australia.

Notably the Society had only two Editors in the first 12 years and only five during its first 27 years. In our 50th year, current Editor, A.E. Cockbain, has held the helm for a nine continuous years

The state geology volumes established a pattern of two issues per year, but for several years, papers were difficult to find to keep to this schedule. Slowly the number of papers submitted began to rise, and since 1993 the journal has had six issues per year.

In 1964, the possibility of a Special Publication series was raised for the first time. This became established with the holding of specialist meetings and publication of the proceedings. Twenty one books have since been published in this series. With the organisation of an increased number of conferences and the severance of links with
ANZAAS, the establishment of an Abstracts serial also became necessary. This was approved in 1980 .

In 1984, the Journal was renamed the Australian Journal of Earth Sciences (AJES) and Blackwell Scientific Publications Pty Ltd were contracted to publish the Journal from Melbourne. The AJES has been redesigned twice since 1984 with better grade paper and a revised format. Authors are now asked to submit the final manuscript on disk and encouraged to provide the figures in digital format.

Commencing in 1997, the AGSO Journal of Australian Geology \& Geophysics was incorporated into the AJES. This allowed a significant expansion in size for the journal in a single non-specialist Australian geological journal. Special thematic issues also became more common as the Journal gained wider circulation. Since 2000 AJES has been available on-line, as well as in hard copy.

\section{The national newsletter}

The first Executive considered that one of the Society's more important functions was the dissemination of personal information and professional news. To further this objective, a News Bulletin was launched in March 1953. Before the publication of the first issue of the Journal in mid-1954 it was the only national communication within the Society. The first Editor was B.F. Glenister.

From its establishment the News Bulletin was given second preference to the Journal, and by 1955 , this position was reinforced by criticism on account of cost and the inclusion of what was regarded as trivial material. Consequently this early News Bulletin ceased publication in 1956.

In 1970, M.J. Rickard proposed the revival of the newsletter and advised that D.F. Branagan had volunteered to act as Editor. In 1973, Branagan's offer to revive the newsletter was accepted.

The Australian Geologist (or TAG) first appeared in January 1974. The first newsletters were prepared by cut and paste, with material from articles and letters being typed by clerical staff at the University of Sydney and printed by photo offset. V.J Morand's letters about conservation and mining in December 1981 and August 1982 provoked the first really lively discussion in TAG.

In 1984, B.J. Franklin took over as TAG Editor. Along with the change in editorship came a complete revamp of the style and presentation. The length of the newsletter gradually grew, now sometimes exceeding 60 pages. The introduction of paid advertising, colour pages and feature articles have raised its profile as well as providing income for the Society.

As well as a message 'From the President' in each issue, the Newsletter contains current information for members in sections including 'Society News', 'Conferences', 'Book Reviews', 'Publications' and 'Obituaries'.

One outstanding feature of the Newsletter continues to be section 'Letters to the Editor'. An article by I.R. Plimer in TAG 61, in
1986 under the heading Point of View and called 'Creation Science-The Work of the Devil' provoked an enormous amount of passionate correspondence which was not finally laid to rest until TAG 71 three years later. Other topics which have caused great interest have been: the Geological Heritage and Monuments controversy: Whether or not universities are teaching basic skills sufficiently well: 'Sustainable' Resources: Possible storage of radioactive waste in Australia: Earth Expansion, to name but a few.

The Newsletter also features 'Special Reports' and 'Special Articles' of widespread interest to members. An example is 'Exploration in a Changing World, -2000 and Beyond' (TAG93). The humorous photographs featured in the 'Know Your Geologist' section have received widespread support over the years. Additionally many smaller items of interest, including amusing bits and pieces and poems are often sent in by members and included. This type of item would almost certainly have received criticism as being too 'trivial' for the Newsletter in the early days of the Society.

After 18 years, TAG editor, B.J. Franklin retired on the occasion of our 50th anniversary, with J. Binns taking over the position.

\section{The standing committees}

In 1956 the Society assumed responsibility for the two existing geology committees of ANZAAS i.e. the Stratigraphic Nomenclature and Tectonic Map.

In time the Society began generating special committees on its own, to tackle major issues facing the earth sciences in Australia. The major standing committees of the Society since its formation, their dates of operation and their initial conveners are as follows :

Stratigraphic Nomenclature (now Stratigraphic Names), 1956-present: H. Raggatt

Tectonic Map, 1956-1972: E.S Hills

Collection \& Recording of Chemical Analyses of Australian Rocks, 1964-1969: G.A. Joplin

Methods of Analysis of Australian Rocks \& Minerals, 1964-1967: A.S. Ritchie

Census Committee, 1964-1971: K.A. Townley

Sedimentary Basin Nomenclature, 19671978: M.A. Reynolds

Professional Qualifications, 1968-1971: N.H. Fisher

Geological Training (also Geological Education), 1967-2000: M.F. Glaessner

Geological Legislation,* 1970-1977: A.F. Trendall

Deep Sea Drilling, 1974-1975: G.H. Packham

Professional Representation,*1975-1981: $\mathrm{K}$. Warner

Geological Monuments (now Geological Heritage), 1974-present: C.D. Branch

Public Affairs, 1988-1990: D.F. Branagan

* These two committees had overlapping interests and were amalgamated in 1977. 
Since becoming a committee of the Society, the Stratigraphic Names Committee has continued its important role of regulating the naming of stratigraphic units in Australia and representing Australia in the associated international forums. The Tectonic Map Committee was eventually disbanded in 1972 following completion of its major work and the formation of the Specialist Group in Tectonics and Structural Geology.

Some of most influential Standing Committees established by the Society have been associated with professional development of geologists. Such issues assumed importance with the minerals boom of the late 1960s. With strong involvement of the West Australian-based Executive, the Geological Legislation Committee (formed in 1970) produced a Code of Ethics for the Society and worked towards legislation to provide for formal registration of geologists. When this latter initiative proved unsuccessful, efforts were diverted into the creation of a professional organisation with the result that the Society was the decisive factor in the creation of the Australian Institute of Geoscientists in 1981 .

The protection of selected geological sites for teaching and scientific purposes arose within various Divisions during the 1960s. By 1974, such work gained national importance following a Government inquiry into the national estate with the consequence that the Society appointed a national convener.

\section{Conferences and meetings}

A major challenge to a national organisation in a geographically large country like Australia is gathering for meetings. For almost 20 years, the ANZAAS conference provided this opportunity, and as a consequence ANZAAS gave the Society invaluable service.

At the same time that Specialist Groups were first mooted in 1964, the Society considered a proposal that a "Specialists' Conference" be held between the regular ANZAAS event. This was supported, and the first Specialists' Meeting was held in Adelaide in August 1966 organised by a South Australian committee, headed by K. Miles and R.W. Nesbitt. The meeting was pronounced to be very successful, so much so that \$A1059 profit was achieved.

A further specialists' meeting was held in Canberra in May 1968 with accompanying business meetings, followed by the very successful specialist Archaean Symposium in Perth in May 1970.

By 1973, the ties that the Society held with ANZAAS had clearly weakened. In 1974, this situation was recognised and the 1st Australian Geological Convention (AGC) was held in Adelaide from 12-16 May 1975. This was organised by the South Australian Divisional Committee under the guidance of R.W. Nesbitt and A.W. Webb with the theme "Proterozoic Geology".
Concurrent with the development of specialist meetings, a single much larger project was coming to fruition. As long ago as 1956 , the Society had been investigating the possibility of hosting the International Geological Congress (IGC) in Australia. By 1970, it was virtually certain that Australia would gain the 25th IGC in 1976, and in 1971 the Society committed to work fully with the Academy of Science to finalise the approval and organise the conference. It may be fairly said that the Society was the major sponsor of the conference and its foremost initiator. N.H. Fisher was the primary instigator through a long gestation period and was Chairman of the Organising Committee and President of the Congress.

The 25th IGC attracted the largest meeting of geologists then gathered in Australia. Regional committees operated in every Australian State in addition to the major Program, Excursion and Sydney committees. Almost a thousand papers were presented and 41 excursions were organised.

In perspective the 25th IGC brought Australian geology into sharp international focus for the first time, and its benefits have been enduring for Australian geology in general as well as to the Society.

Following the 25th IGC, the Society has established a regular and successful series of Australian Geological Conventions with a clear organisational framework. In addition, it has been the major sponsor of several further international symposia, including the 12th International Sedimentological Conference in 1986, Bicentennial Gold in 1988, further Archaean Symposiums, as well as numerous smaller specialist meetings. In the past 30 years, conferences have arguably become the major events on the Society's calendar.

\section{Grassroots}

The grassroots of the Society were, from the beginning, at the local level of Divisions and Branches. In Melbourne and Adelaide, the local division was created by the transformation of an existing locally-based geological association. In Canberra, an existing lecture meeting within the Bureau of Mineral Resources was transformed into meetings of the Commonwealth Territories Division. The regional variation within the Society remains considerable and this has been further enhanced by the creation of a Northern Territory Division in 1998.

Most Divisions have had a long association with university geology departments and these institutions have often provided the venue for the regular meetings that occur around Australia.

The Queensland Division has been particularly active in field activities since the foundation of the Society. From 1964 until 1996, these field trips developed into extended field conferences of many days duration coupled with the production of guide books which have become important scientific references in their own right. Since
1996, field conferences have been held in conjunction with the several national and international conferences that have been held in Queensland.

During the 1960s, the South Australian Division conducted highly successful Public Field Days, which attracted hundreds of people. This activity only lapsed with the emergence of a strong amateur 'Field Geology Club' in Adelaide during the 1970s.

The Divisional newsletters were well established before TAG was founded in 1974. Here too Tasmanian Division excelled for many years with a publication that included cartoons, letters and crossword puzzles in addition to more routine business.

The Divisions have also been at the forefront in preserving local geological sites or monuments for teaching or scientific research. This work commenced as early as 1960 in the Australian Capital Territory. The South Australian Division has been especially strong in this regard with the production of several volumes describing the State's geological monuments. During the early 1970s it was also instrumental in securing the preservation of Late Palaeozoic glacial features at Hallett Cove, a site of international significance.

Most Divisions have also assisted geological education at various levels. Prizes are often sponsored for excellence in geology at schools or universities. In a different response to geological education, the Victorian Division published a 'Victorian Geology Excursion Guide' in 1988 and followed this with a book entitled 'Introducing Victorian Geology' in 1991 which has become a widely-used text book.

Currently the Victorian and Tasmanian Divisions are preparing new volumes on the geology of their respective States.

Specialist Groups have added a different dimension to the Society with their nationwide membership and focus on specific geological specialities.

Some groups such as the Australasian Association of Palaeontologists have established separate scientific journals, viz 'Alcheringa', which has had continuity and wide international recognition since its inception in 1975. A palaeontology Memoir Series was also commenced in 1983 and has produced 25 volumes to date. This Group hosted the first International Palaeontological Congress in Sydney in July 2002.

Conference activities have been the life blood of most specialist groups. In 1986, the Australasian Sedimentologists Group was especially active in this regard with major involvement in the 12th International Sedimentological Congress and International Volcanological Congress. From 1984 to 1996 it also published 11 field guides.

Some Groups such as Coal Geology and Economic Geology have had strong private sector involvement. Other groups, such as Tectonics and Structural Geology have had an especially strong field program with asso- 
ciated regional conferences and continue to produce regular field guides.

In addition, the Tectonic and Structural Geology as well as the Earth Sciences History Group have edited special issues of international journals viz: 'Tectonophysics', 'Journal of Structural Geology' and 'Earth Sciences History'.

Every specialist group communicates with its members via a regular newsletter.

\section{Honours and awards}

One of the major contributions of the Society has become the recognition of individual contributions within the geological sciences.

Three of the Society's original Honorary Members have subsequently been further recognised in the F.L. Stillwell Award, W.R. Browne Medal and the Mawson Lecture.

From 1979, the W.R. Browne Medal has been awarded for distinguished services to geological sciences in Australia. The first recipient was foundation President E.S. Hills. The Stillwell Award is awarded for the best paper, published in any one year in the Journal. It was first awarded to B.E. Hobbs in
1966. A Mawson Lecture was first given at the Australian Geological Convention by B.N. Runnegar in 1981.

Since 1990, the Society has created additional awards in specific geological specialities. The S.W. Carey Medal, since 1992, has been awarded to a person distinguished in the field of tectonics (inaugural recipient J.J. Veevers), whilst the Joe Harms Medal has been awarded since 1994 in recognition of exploration excellence and ore deposit discovery. The first recipient was J.E. Harms.

These national awards have also been complemented by awards and commemorative lectures in most Divisions as well as the Economic Geology and Tectonics and Structural Geology Specialist Groups.

\section{Conclusion}

The Geological Society of Australia has trod an energetic pathway since its first tentative beginnings 50 years ago.

Today the Society is a significant professional organisation with assets totalling more than \$A1 million and an annual income exceeding $\$ A 300,000$. It ranks as one of the largest geoscience organisations in the southern hemisphere.

The current President of the Geological Society of Australia is Dr John Foden, University of Adelaide, john.foden@adelaide. edu.au; and the Honorary Secretary is Dr Patrick James, patrick.james@adelaide. edu.au. The Society's office can be contacted at misha@gsa.org.au whilst the Society's website is www.gsa.org.au.

This article is a synopsis of a larger paper prepared for the Society's 50th anniversary by Dr Barry Cooper from the Society's Earth Sciences History Group and published as a supplement to 'The Australian Geologist' Newsletter 123.

\section{Dr Barry J. Cooper}

Geological Society of Australia Inc.

Suite 706, 301 George Street

Sydney NSW 2000

AUSTRALIA

\section{Global interaction of science, technology and policy}

In the last few years, the United Nations, through its multiple commissions, committees and other organisations, has contributed towards moulding the current situation and the possible evolution of scientific and technical knowledge on a global scale as well as its transfer mechanisms for development. Two large international meetings have recently set out the foundations for this: The World Conference on Science held in Budapest three years ago, which was organised by UNESCO with the co-operation of the International Council for Science, and the Conference of Trade and Development (UNCTAD-X), which was held in Bangkok in February 2000. Both conferences agreed to draw up Declarations where the principal directives to follow were recommended: the Declaration on Science and the Use of Scientific Knowledge and the "United Spirit of the Bangkok Agreement".

These large meetings have helped to establish the principal means of achieving wider and improved access to "knowledge" for everyone, incorporating the necessary components of development and technological transfer, which are vital for any adaptation to the needs and economies of each country. However, they have also highlighted the tremendous differences and inequalities which exist, and which lead some countries to almost continually ask for aid and concrete action and others to promote the protection of their economic interests. Therefore aid, for one reason or another, almost never reaches those peoples and collectives that truly need it.
As a result, the Functional Commissions of the United Nations are very important; these are commissions of experts, where scientists, diplomats, politicians and technicians form a multidisciplinary vision and offer their analysis, predictions and recommendations to the Economic and Social Board (ECOSOC) and to the General Assembly of the United Nations. In our case, we refer to the activities of the Commission of Science and Technology for Development (UNCSTD). This is a relatively new organ of the United Nations (founded less than 10 years ago), which is gaining importance thanks to the belief that many global decisions cannot be taken without previous knowledge of the scientific and technological principals which sustain them.

The UNCSTD is a Functional Commission of the Economic and Social Council of the United Nations, which was created in 1992 during the period of restructuring and strengthening of all their Functional Commissions. It arose as a consequence of the fusion of the Intergovernmental Committee of Science and Technology for Development (IGCSTD) and its Advisory Committee, which were installed following the United Nations Conference in Vienna 1979. The role of the UNCSTD is to act as a Commission of Experts for the General Assembly of the United Nations on relevant themes and as a guide to prevent future disagreements in science and technology by drawing up global recommendations. The UNCSTD is currently made up of 33 Member States; Eight from Africa, seven from Asia, six from Latin America, four from Eastern Europe and eight from Western Europe and other States. The secretariat of the Commission has been the responsibility of the UNCSTD since 1993 and Spain has had the vicepresidency of the representation of Western Europe and Other States Group since 2001. The UNCSTD also has a Gender Advisory Board, whose activities have recently been supported by the Commission, and which are interconnected with multiple statutes from the United Nations and other organisations in which Spain, Brasil and Tunisia participate as Delegate Representatives of the UNCSTD.

According to the functional character of the UNCSTD, the delegates cover an ample range of activities and areas of expertise. In many cases the additional opinion of other specialists, who contribute as assessors in the analysis of the questions, is also sought. To give some examples from the past two years, we can highlight the contributions of professors and personalities such as Jeffrey Sachs and Calestous Juma from the Centre of International Development of the University of Harvard on one of the panels in the year 2000. More recently Karl P. Sauvant (UNCTAD), Shirley Malcolm (AAAS), José María Figueres (Centre for the Global Agenda, World Economic Forum), Lynn Mytelka (UNU/INTECH), George Nicholas von Tunzelmann (Science \& Technology Policy Research, University of Sussex), have also participated. One of the most prestigious advisory reports drawn up by UNCSTD - recognised by ECOSOC- 
was that titled Knowledge Societies, directed by Robin Mansell and Uta When from the University of Sussex and by Fernando Chaparro (Colombia) y Geoffrey Oldham (UK) ${ }^{(1)}$. Here more than 60 experts made a detailed analysis of information and communication technology and its implications for the development of societies. It is no surprise that the next Commission panel is related to this question.

The last ordinary session of the UNCSTD, which was celebrated in Geneva, showed how important this Commission can be. Rubens Ricupero, Secretary of the UNCTAD commented on the decisive role which the UNCSTD could carry out in its collaboration with the "ICT task force" and with the Third World Science Academy. The resolution of the "Group of 77" - the major coalition of Third World, made up of 133 countries-was also important. They supported and recommended strengthening the Commission's activities in a specific document. However, probably the most categorical support came from the ECOSOC. Thanks to its clarity and strength, this was a surprise to some and a backing for those who had emphasised the need to strengthen the questions of science and technology for development in such a relevant international area. During the videoconference held between Geneva and New York, the members of the bureau of the ECOSOC defined the UNCSTD as the "Best Functional Commission" and invited it to hold more meetings if necessary, suggested its future role as Expert Commission for the implementation of the 'Millennium Declaration' and for it to follow the next meeting for Sustainable Development in Johannesburg 2002 and the Information Societies 2003. Other important initiatives are:

a) the establishment of links with other United Nations Functional Commissions

b) the promotion from UNCSTD of "science and technology diplomacy" and,

c) the excellent role carried out by the "Science and Technology for Development Network STDev: http://www.unctad.org/ STdev/." This electronic network houses the UNCSTD's initiatives, decisions and documents. It provides information on scientific and technological activities and programmes within the United Nations system and among intergovernmental and non-governmental organisations, and builds awareness of scientific and technological developments that are particularly important for developing countries and countries with economies in transition.

The UNCSTD, at its fifth session held in Geneva from 28 May-1 June 2001, selected "Technology Development and Capacity-Building for Competitiveness in a digital society" as the substantive theme for its inter-sessional period 2001-2003. The work programme for this inter-sessional period will be carried out by panels addressing different aspects of the main substantive theme, namely, technology transfer, diffu- sion and capacity-building with particular attention to absorption and applications of information and communication technologies (ICT). The UNCSTD's multi-disciplinary links with other Functional Committees and more thematic Committees (e.g. Commission on Sustainable Development, Committee on Energy and Natural Resources, Commission for Social Development) allow many future projects to be organised. For example, within the scope of the Earth Sciences, the discipline known as socio-geoscience $^{(2)}$, which pays special attention to resources, population and environment, is crucial to deal with the difficulties faced by human beings and provide a solid scientific basis in order to realise the sustainable development. We agree with McLellan and Cordani ${ }^{(3,4)}$ when they indicate the need for integration between geology and public policy and the increasingly important role that geosciences will surely play on the road towards a sustainable society and a greater understanding of the Earth.

However, despite the importance of Earth Sciences to society, geoscientists still participate very little in the international forums with responsibility for science, technology and policy. Some names such as Harrison Schmitt (United States Senator representing New Mexico), Claude Allegre (French Minister of National Education, Research and Technology), Enric Banda (Secretary General, European Science Foundation), Geoffrey Oldham (Chairperson of the United Nations Advisory Committee on Science and Technology for Development and Co-Chairperson of the Gender Advisory Board of the UNCSTD, Lynn Moxham (UNESCAP, World Bank and Canadian International Development Agencies), Farkhonda Hassan (Secretary-General of the Egyptian Council for Women (NCW) and Co-Chairperson of the Gender Advisory Board of the UNCST, stand out among others.

In a seminar held during the 31 th International Geological Congress various aspects were identified related to the geosciences which typified the so-called "New Earth Science Revolution"(5). They attempt to collect the current position of geosciences in "thematic subjects" and to predict what their future development will be. We believe that contacts should be strengthened and forces joined between the different Commissions and Committees of the United Nations in an attempt to give this social component and the most applied of the geosciences, a relevant role in the international programs. An important first step has recently been taken in relation to the excellent IGCP program: a joint endeavour of UNESCO (United Nations Educational, Scientific and Cultural Organisation) and IUGS (International Union of Geological Sciences). This was launched in 1972 to facilitate co-operation among geoscientists across frontiers and boundaries and currently operates in about 150 countries and involving several thou- sands of scientists. The International Union of Geological Sciences (IUGS) has established a Working Group on Public Affairs to share information on geoscience-related public policy activities around the globe ${ }^{(6)}$.

A survey was sent to its national members asking how geological organisations around the world are engaged in activities related to public policy. Eleven surveys were returned from Europe, four from Africa, three from the USSR and two from Asia ${ }^{(6)}$. This section of Episodes could be an ideal forum to solicit the proposals, not only from governments, but also from scientific and technological associations, or any institution which has something to offer the UNCSTD from their own specialised areas, to in our case: a) distribute the range of possibilities of geoscience in many social sectors; b) give incentives to geo-scientists to participate and be involved as much as other professions; and c) contribute so that the transfer of knowledge and technology to developing countries is something more than just words and good intentions.

\section{References}

(1) http://www.sussex.ac.uk/spru/ink/knowledge. html

(2) Zhao X, Yin J Z, Yang YQ, 1997, Sustainable geology-Sociogeosciences. Episodes 20 (2): 84-88.

(3) McLellan E., 2000, A View From the Hill Geotimes. Political Scene, October 2000.

(4) Cordani, U., 2000, Briefing from the 31st International Geological Congress. 31st IGC: Geology and sustainabile development.

(5) Robbins, E.I., 2000, The New Earth Science Revolution. Seminar given at USGS/Reston on 20 September 2000. http://www.geochina.org/ geochina/report/9-23-2000.htm

(6) Applegate, D., 2001, Crossing Geopolitical Borders. Geotimes. Political Scene. August 2001.

\section{Dr. Jesús Martínez-Frías}

Spanish representative and

Vice-Chairperson of the UNCSTD

Laboratory of Planetary Geology

Centro de Astrobiologia (CSIC-INTA)

Madrid

SPAIN

E-mail: martinezfrias@mncn.csic.es

\section{Dr. Mongi Hamdi}

Economic Affairs Officer DITE/UNCTAD

Geneva

SWITZERLAND

E-mail:Mongdi.Hamdi@unctad.org 